\title{
"COST" AS A SUBSTITUTE FOR "VALUE" IN UTILITY RATE BASE DETERMINATION: A COMMENT ON DR. BAUER'S POSITION
}

\author{
SAMUEL FERGUSON†
}

I

WRITING in the June issue of the Yale Law Jourial, ${ }^{1}$ Dr. John Bauer urged strongly that "prudent investment," as defined by him, be accepted as the proper rate base for use in determining the return permitted to public utility companies. I agree with his thesis that "cost" rather than "value" should be the dominant consideration in the formulation of a rate base. However, in view of the stated attempt of his article to exorcise the "incanted . . . concept of "fair value," "I it is extraordinary that Dr. Bauer should suggest the retention of one aspect of the "value" theorem, through the reduction of the item of historical cost by "depreciation" accruals. This fundamental misconception of the proper treatment of depreciation distorts his definition of "cost" and, if accepted by regulatory agencies, would lead to inequities and to unnecessary replacement expenditures, with a temptation to increase the return to stockholders at the expense of otherwise attainable rate reductions.

Before discussing the fallacy in Dr. Bauer's thinking and indicating a reasonable program for the treatment of the related but not identical problems connected with depreciation and the accumulation of depreciation reserves, it is appropriate to reiterate the major threads in his argument. In Dr. Bauer's formulation, the question of "value" is declared to be wholly irrelevant to the determination of the amount of permissible return. Recent court decisions are held to have cleared the way for the desirable demise of "fair value" as a rate base ingredient. Its final discard is deemed to have been presaged by the decision of the United States Supreme Court in 1942 in the Natural Gas Pipeline Company case. ${ }^{3}$ Dr. Bauer finds no conflict between Chief Justice Stone's statement, in the majority opinion, that "The Constitution does not bind rate-making bodies to the service of any single formula or combinations of formulas" \&, and the statement in the concurring opinion of Justices Black, Douglas, and MIurphy that

† President, The Hartford Electric Light Company.

1. Bauer, The Establishment and Administration of a "Prudent In'esiment" Rate Base (1944) 53 YALE L. J. 495.

2. Bauer, supra note 1 , at 495 .

3. Federal Power Comm. v. Natural Gas Pipeline Co., 315 U. S. 575 (1942).

4. Id. at 586 . 
courts cannot "concern themselves with any issues as to the economic merits of a rate base" and that the Federal Power Commission is now freed from the compulsion of admitting evidence on reproduction cost or of giving any weight to the element of "fair value." The Commission may now adopt if it chooses, prudent investment as a rate base.

Any residual doubts as to the necessity for considering "fair value" are considered to have been dispelled by the decision of the Court in 1944 in the Hope Natural Gas case, ${ }^{\circ}$ in which it was stated:

“... Under the 'statutory standard' of just and reasonable it is the result reached not the method employed which is controlling. . . . The fact that the method employed to reach that result may contain infirmities is not then important."

Dr. Bauer concludes that "No particular rate base provisions are imposed, provided that the rates as fixed are all-around 'just and reasonable.'" ?

Whether or not our shift in concept is legally admissible everywhere it is a fact that the utility industry has recognized the increasing public acceptance of the cost criterion and in its financing has sought to adjust itself to acceptance of cost as the new basis for rate-making. This has been facilitated by the very large amount of new property built under price levels very much higher than prevailed when the original plant and equipment were constructed. This replacement of old properties, together with additions of new plant has brought utility financing nearly into accord with costs and thus diluted and made negligible earlier financing predicated on the "value" concept.

\section{II}

As indicated above, I am completely in accord with Dr. Batuer's conclusion that an adoption of cost in place of value has been desirable from the consumers' standpoint and has been in the interest of investors in public utility securities. But after interring the "value" concept, Dr. Bauer proceeds to depart from the goal of applying a straight cost standard by asserting that utility rate bases should be predicated not on original cost, but on "original cost less depreciation." It is at this point that I am forced to dissent vigorously from his views.

On this subject Dr. Bauer declares:

"If proper plant and depreciation accounting has been adhered to, the total cost of the plant units less the depreciation reserve, is equal, at any given time, to the investment actually made, the full amount

5. Id. at 606 .

6. Federal Power Comm. v. Hope Natural Gas Co. 320 U. S. 591, 602 (1944).

7. Bauer, supra note 1 , at 504 . 
having been preserved. But if adequate provisions for depreciation have not been made directly or indirectly, interest and dividends may have been paid from the consequent showing of corporate net income and the investment correspondingly impaired ....

“' 'Prudent investment' is viewed at times, especially by people who would gain thereby, as consisting of the gross original cost of all the plant units devoted to public use without deduction of past depreciation due to physical and functional causes. The inapplicability of this gross cost view appears clear if one considers that once a corporate investment is made it must subsequently be fully maintained or it will be impaired or dissipated. Such full maintenance consists of ordinary repairs plus proper provisions for depreciation as it accrues, both charged regularly to operating expenses ...." 8

I believe this argument is erected on two fallacious assumptions: (a) that "cost" is affected by depreciation; and (b) that the loss caused by depreciation is charged to expense as it actually accrues.

The fatal defect of the first assumption is that it smuggles a valuation factor, i.e., the depreciation of plant and equipment, into the simple historical task of recording cost. Yet it should be obvious that the factors which compose "cost" and "value" are not synonymous and that the concepts must not be confused. Strong testimony to this effect was given by C. W. Smith, Chief of the Accounts, Finance, and Rates Division of the Federal Power Commission in the Arkansas Pozier \& Light Co. ${ }^{\mathfrak{B}}$ case:

"I agree that values are in a state of flux and I don't think any accountant would argue that cost represents value. Cost represents cost. I don't claim that cost represents value. I believe that value, however, is an unnecessary process in the fixing of rates ${ }^{10}$... I agree that the value of any property is the present worth of what it will earn in the future. I agree, too, that the value of physical properties of a business which is not earning money is scrap value." ${ }^{11}$

There is no doubt that both appreciation and depreciation of property materially affect values; but they cannot possibly alter the figure of actual original property cost. Cost and value may indeed be identical at the date of construction. But except through the fortuitous circumstance that appreciation exactly offset depreciation in the case of a particular property, cost and value could never be identical in subsequent years. Consequently, when cost is substituted for value as the basis for regulation, it necessarily follows that depreciation, i.e., loss in value-no longer

8. Id. at 506 .

9. In the Matter of Arkansas Power \& Light Co., Arkansas Department of Publie Utilities, Docket No. 225 (1944).

10. Id., p. 12 of transcript, for morning session, Feb. 24, 1944.

11. Id., p. 13, transcript for Feb. 23, 1944, session. 
should be taken into consideration, unless it has gone so far as to bring about either withdrawal of a particular piece of property from service, or its classification as no longer "used and useful."

The 1943 Report of the Committee on Depreciation of the National Association of Railroad and Utilities Commissioners is led by a similar confused commingling of value and cost concepts to conclude that the depreciation reserve is not a separate fund, but a contra entry, ${ }^{12}$ which reduces the fixed capital account. This fallacious argument probably stems from an analogy to the accounting treatment of coal consumption in the preparation of a year-end balance sheet. In this situation, the coal inventory is very properly reduced by a contra entry equal to the charge to the expense account. ${ }^{13}$ Since the burned coal is obviously no longer capable of rendering service or creating earnings, failure to make the contra entry would render the balance sheet untruthful. A very different situation exists in the case of a utility company's lines and equipment. The fact that an item for depreciation is included each year in a company's expense accounts does not mean that any property has actually disappeared. The same lines and equipment are still in operation, still rendering service to the public, still producing earnings. The fact that the future life of any given piece of equipment, after a year of service, is one year less than it was before cannot possibly affect its actual cost although it obviously would reduce its market value in the event of a sale.

Dr. Bauer's second fallacy is to confuse the fact of depreciation with the preparations made for reimbursement to the company for the cost of withdrawn equipment. His position would seem to be that loss of value takes place with the same uniformity and regularity as charges to expense, made to facilitate recoupment of the cost of the property at the time of its withdrawal from service. However, except for the slight wear and tear component, the loss of value arising from physical or the more potent functional causes occurs very irregularly, both as to magnitude and time of incidence. In consequence, the depreciation reserve of any given company represents nothing more than a fund to permit reimbursement for capital when its useful life terminates. In no sense do such reserves, as they exist at any given date, measure the depreciation which has actually taken place in that property, as of that date. Neither does the depreciation reserve on a cost basis have any relation to the cost of replacement of property withdrawn. It is the obligation of the company to maintain the service either by replacement of property withdrawn or by other means whatever the cost may be. It is the cost of plant withdrawn which is to be reimbursed through the depreciation reserve when that property has reached the end of its tuseful life.

12. Report of Cossmittee on Deprectation of National Association of Railmoad ANd UTLITIES Comarissioners (1943) $\$ 13$ of Summary and p. 32.

13. Federat Power Commission Uniform System of Accounts (1937) \& 131. 
III

The inequity Dr. Bauer seeks to correct by the "cost less depreciation" standard is indicated by his statement that:

"If the original cost of plant were included in the rate base, the company would get a return not only on its own actual or unimpaired investment, but also on the anronnt of customer contribution provided in the rates for the purpose of conserving the corporate investment." 14

In the main, I am in accord with the objective indicated in the quotation, namely, the elimination of inequitable enrichment of investors arising out of the use of money paid in by customers "in order to maintain the integrity of the investment in the service rendered." 15 However, as demonstrated below, Dr. Bauer's suggested cure would merely substitute one inequity for another. ${ }^{18}$ In fact, because of the contradictions involved in the concept of original cost less depreciation, the net property standard even fails to comply with the principles enunciated by Dr. Bauer as requisite for an effective rate base $:^{17}$

"Establishment of a rate base which can be systematically administered requires (1) the adoption of a precise concept, (2) exact determination of initial amounts, and (3) continuous factual adjustments as changes in the operating properties take place in order that accounts and records may show definitely at any time the amount on which the company is entitled to receive a reasonable return. . .."

The proposed "net property" base meets the first two of these tests, but fails to reflect "factual adjustments as changes in the operating properties take place...." Since under a cost basis of regulation, changes in value as of any given date have no place on a utility's books of account or in its rate base, "factual adjustments as changes in the operating properties take place" can, properly speaking, be only such entries as represent withdrawals from, or additions to plant and equipment.

On the other hand, the utilization of undepreciated original cost or gross property as a rate base would permit compliance with all three of Dr. Bauer's tests. Since, as indicated above, under the recent decision, ${ }^{18}$ the formula applied by the regulatory body is immaterial, utilization of the original cost base could be required by utility Commissions, provided the ultimate requirement of a just and reasonable return on the investment

14. Bauer, supre note 1 , at 506-507.

15. See Lindheimer v. Illinois Bell Telephone Co. 292 U. S. 151, 167 (1934).

16. See Report of tee Special Comanittee on Deprectation of teg Azrerucali Bais

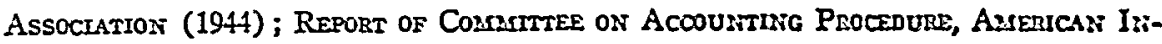
STITUTE OF AcCountants (1944).

17. Bauer, supra note 1 , at 506 .

18. Federal Power Comm. v. Hope Natural Gas Co., 320 U. S. 591 (1944). 
was met. In any particular rate case, it would be just as easy for the regulatory agency, after it had made its determination as to the "just and reasonable" net income of a company, to phrase the permissible sum as a lower percentage on gross property as to allow a higher percentage on "net property." As a control and guide to operations an accounting system based on cost, without any arbitrary writedown such as occurs in an effort to determine net property, has many desirable features and avoids the pitfalls inherent in the net property rate base.

\section{IV ${ }^{\prime}$}

Dr. Bauer and the Report of the Committee on Depreciation of the National Association of Railroad and Utilities Commissioners seek to phrase and treat as a single question, two separate and distinct problems:

1-The devisal of a method whereby the users of utility service shall be assessed the original cost of physical plant, which is consumed over a period of years.

2-The devisal of techniques for according equitable treatment of money, paid in by consumers (to reimburse for property) and retained by the company, pending the actual retirement of the property.

Dr. Bauer and the authors of the NARUC report assume that both problems may be equitably solved by establishing "original cost less depreciation reserve," or so-called "net property," as the rate base. This wellintentioned attempt at over-simplification results in confused definitions and is bound to eventuate in gross inequities, including the inducement to premature and uneconomic replacement of property.

Of course, utility managements must make preparation for the eventual and inevitable retirement of fixed capital by accumulation of a reserve. But the collection of this money in preparation for eventual retirements does not justify a writedown of cost on the books or in the rate base, on any ground dependent on any aspect of depreciation. If amortization of capital had received legal sanction and the funds accumulated for this purpose were paid out to investors (which is not the case), concomitant writedowns in the cost items would be justifiable. However, the court has not generally approved the amortization principle. ${ }^{10}$ In any event, the amortization doctrine has nothing in common with depreciation, and the advisability of amortization should be considered on its own merits, without the confusion introduced by misuse of depreciation terminology.

19. Amortization of capital was approved in Federal Power Comm. v. Natural Gas Pipeline Co., 315 U. S. 575, 593 (1942), but this approval was carefully qualified as applicable to " $\mathrm{a}$ business which can exist for only a limited term ..." 
V.

The inequities occasioned by deduction of depreciation reserve accruals from capital accounts in the past were obscured by the rapid growth of the utilities industry. The results become apparent, however, when the problem is simplified by considering the case of a static company, as in the subjoined analysis. Most students will concede that this assumption is not academic and that the industry is growing towards this static position. (In fact, this state of affairs already exists in lesser degree, whenever the credits to a particular company's depreciation reserve in any given year exceed the sums expended on additions to, or replacement of, property. A recent report by the Federal Power Commission demonstrates that this situation prevailed for the industry as a whole during $1942 .^{23}$ )

\section{Case One, Example of Inequitable Condition}

1. Assume that a particular piece of property had cost $\$ 1,000,000$ and that $6 \%$ was considered a fair rate of return, i.e., $\$ 60,000$.

2. Assume the depreciation reserve was accumulated on a straight line basis and that the reserve after a period of years has reaclied the sum of $\$ 200,000$.

3. Assume the company's capitalization was $\$ 400,000$ of $4 \%$ bonds and $\$ 600,000$ of stock.

In this situation, the $\$ 60,000$ of permitted earnings, after covering the $\$ 16,000$ required for bond interest annually, would leave $\$ 44,000$ for the payment of dividends to stockholders and the accumulation of a surplus.

Under the above assumption of an accumulation of $\$ 200,000$, and if the "net property" concept were applied, the rate base would have to be reduced to $\$ 800,000$. Accordingly, under the maximum $6 \%$ rate of return rule, permitted earnings from operations would be cut from $\$ 60,000$ to $\$ 48,000$ annually. Even assuming the depreciation reserve were invested in suitable securities, it is dubious that the return on the fund would be more than $2 \%$, or $\$ 4,000$. Accordingly, the company's total earnings would be $\$ 52,000$; after deduction of bond interest, the sum available for payment of dividends and accumulation of surplus would be only $\$ 36,000$, or $82 \%$ of the former amount. The full fair return, i.e., $\$ 60,000$, could not again be earned, until withdrawals had been made to the full extent of the reserve.

The possession of the $\$ 200,000$ reserve by the company is in no sense a return of principal to investors; the assets of the reserve were paid in for

20. Federal Power Comsurssion Release, Financial Record of the Electrucal UTILITY INDUSTRY 1937-1942 (1943) 7. 
the specific purpose of covering retirements and must eventually be used for this purpose.

In the above example, the problem has been analyzed as it would exist when a reserve of $20 \%$ of cost had been accumulated. However, it is universally admitted, that the application of the presently approved straight line method of depreciation eventually results in accumulation of a reserve of $45 \%$ of the original fixed capital account. ${ }^{21}$ Under the "net property" concept, there would be a corresponding decrease in the permitted return, although presumably identical service was being rendered to consumers and although there had been no return to the investors, who furnished the capital.

There is no justice in a concept which requires stockholders to accept a continuously diminishing income as the reserve grows. Nor is there any likelihood that regulatory bodies would rule as fair a larger and larger rate of return with the growth of the reserve.

It is apparent from the above discussion that utility managers in the interest of their investors would be under constant temptation to make premature and uneconomic replacements of plant and equipment in order to diminish the size of the reserve in relation to property cost. Once again the situation is best illustrated with a specific example.

\section{Case Two}

The Hartford Electric Light Company owns an old low pressure steam plant built 40 years ago; the ages of existing turbines vary from 25 to 30 years; total nameplate rating is $36,000 \mathrm{KW}$. The fuel consumption of this plant is very high (2.2 lbs.) as compared to modern performances; its operation, however, is simple and extremely reliable. This plant has been run for so few hours, during the past ten years, that its efficiency is wholly immaterial. However, the retention of the plant is essential for the rendition of full continuous service, and it fulfills all requirements of a necessary reserve to the modern $40,000 \mathrm{KW}$ units, located in a newer and more efficient station, which normally carry the load.

The old plant is carried on the books at its cost figure of $\$ 3,000,000$. During its life the depreciation rates, as charged by the company to expense, have averaged in excess of $31 / 2 \%$, so that it might be said to have been fully amortized. Replacement with a new and efficient unit has every appearance of reasonableness, save that there is no service need for a new plant. At today's prices, the cost of replacement with an efficient high pressure unit would be $\$ 4,000,000$.

21. Lindheimer v. Illinois Bell Telephone Co., 292 U. S. 151 (1934), concurring opinion of Mr. Justice Butler, at 181 ; Report of Comsittee on Depreciation of National Association of Railroad and Utilities CoMmissioners (1943), 220; (1944) 69. 
The total original cost of all properties of the Hartford Electric Light Company is approximately $\$ 40,000,000$; the depreciation reserve now stands at $\$ 10,000,000$. If the "net property" theory were applied, under the conditions outlined above, the Company's permissible earnings, at an assumed $6 \pi / 2 \%$ rate, would total $\$ 1,950,000$, as by the subjoined table:

\section{Before Replacement}

Original cost

Depreciation Reserve

$$
\$ 40,000,000
$$$$
10,000,000
$$

Rate Base

Permitted Earnings at $61 / 2 \%$

$\$ 30,000,000$

$1,950,000$

If, however, the old low pressure units were replaced by a new unit, costing approximately $\$ 4,000,000$, the permissible earnings figure would mount to $\$ 2,210,000$, as demonstrated below:

After Replacement

Original Cost
Depreciation Reserve

Rate Base

Permitted Earnings at $61 / 2 \%$

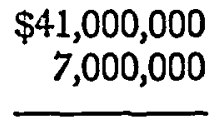

$\$ 34,000,000$

$2,210,000$

This situation presents a great temptation to perpetrate the economic waste involved in spending $\$ 4,000,000$, although, as indicated previously, there would be little benefit in terms of reduced operating costs or any increase in useful capacity. Even on the assumption that the company would have to borrow all the funds needed to defray the construction costs, erection of the new unit would materially benefit stockholders. The necessary $\$ 4,000,000$ could readily be borrowed at $3 \%$; subtracting the $\$ 120$,000 of new interest charges from the $\$ 260,000$ of increased earnings permitted by erection of the new unit would leave a net increase of $\$ 140,000$ of income allocable to stockholders.

Moreover, the increase in consumer payments to the company would materially exceed the $\$ 260,000$ of augmented earnings, as the increase in income would necessitate larger income and electric energy excise tax payments. The addition to the capital account would also occasion an increase in the annual charge for depreciation. Cumulatively, construction of the new unit would probably permit the company to collect more than $\$ 350,000$ from consumers anually in the form of prices higher than necessary without any useful purpose being attained thereby. 
If, on the other hand, the regulatory commissions utilized undepreciated cost as the rate base, there would be no temptation to benefit stockholders at the expense of consumers by unnecessary plant expenditures. Since the regulatory body has the final authority to determine what constitutes a fair return (assuming there is no question of confiscation), it could readily provide for application of a lower percentile figure on the undepreciated base than would be required on a net property base, and still arrive at the same fair dollar return. Consistent application of undepreciated cost as a rate base would prevent unnecessary replacements without in any way deterring those additions to plant and equipment which would be economically beneficial.

The importance of this problem will be accentuated after the war because the probable elimination or dimunition of the excess profits tax burden will bring a reduction in utility expenses. If undepreciated cost is used as the rate base, it will be possible in most instances to convert these cost savings into an instrument for reducing rates. However, if Dr. Bauer's "net property" concept is adopted, managements will be tempted to make premature retirements as a legitimate method of utilizing the reduction in expense to augment permissible earnings, rather than to pass rate decreases on to consumers. Undoubtedly, many managements would resist this temptation, but it seems senseless to adopt a rate base formula which offers so great an inducement to wasteful expenditure.

\section{VI.}

I believe it is essential to separate the problem of providing for depreciation from the equally important problem of determining the equitable treatment to be accorded to customer payments, held by the company for the purpose of covering retirements; and to solve each problem on its merits.

1. The regulatory agency, of course, should have the responsibility for fixing the desirable size of the replacement reserve. Except in freak cases, 15 to $20 \%$ of fixed capital, in lieu of the present $45 \%$ maximum figure, should be ample to ensure continuance of satisfactory service to consumers and to protect the investors' equity in the property. ${ }^{22}$

The regulatory body should then devise a simple formula, which could be applied to the historical data on the books of utility companies to determine the annual accruals to the depreciation reserve. This formula should

22. The Report of the Edison Electric Institute to the Committee on Depreciation of the National Association of Railroads and Utilities Commissioners of Feb. 2, 1944, indicated that the maximum industry-wide call on the reserve in any one year had never exceeded $5 \pi / 4 \%$ of fixed capital. The figures used in the text visualize a safety factor of 3 or 4 . 
be designed to create and maintain the reserve at the desired figure. Management should not be permitted any discretion in the annual application of this formula in its earnings statement.

The present technique is to stipulate an arbitrary annual accrual on the basis of guesses as to provable service lives without regard to the size of the reserve. The foregoing method proposes to have the regulatory agency fix the size of the reserve and then let the amount of the annual accruals be determined by a formula based on experience.

2. If customers' money is used for ordinary corporate purposes, it should be credited with equitable earnings out of the permitted return. The amount of these customer earnings should be specified by the regulatory agency, with recognition of the fact that the company could obtain funds necessary for expansion elsewhere, if an undue share of the earnings were allocated to the senior money, constituting the assets corresponding to the reserve liability.

Earnings credited to the reserve from the permitted total company return would correspondingly reduce the amount to be charged to expense as depreciation in accruals. As the reduction in expense directly affects the permissible rate of return, the earnings would benefit the customers, to the same extent as though paid to them in cash.

\section{VII}

The problem of determining proper methods of depreciation accounting has been needlessly complicated by the attempt to devise one pat solution for the two problems of collecting the original cost of property and of according fair treatment to consumers' money retained by the Company, pending retirements of property.

Once the distinction between these problems is recognized, there will be opportunity for public opinion to consider and evaluate proposed solutions for each. The present confusion makes it impossible for anyone but an expert to understand the issues at stake or to realize that Dr. Bauer's "net property" concept entails an arbitrary writedown of fixed property accounts. Such writedowns, although they have an exactly reverse effect to the "write ups" in property accounts placed on the books in the past by many utility managements, are subject to many of the same objections. It is scarcely to be expected that public opinion-which has reacted so adversely to arbitrary alteration in historical cost figures, when made in an upward direction, as to require retroactive elimination of such changeswill approve arbitrary alterations, when made in a downward direction, unless the issues are made clear.

Precise delimitation of the issues of debate between Dr. Bauer and myself is assisted by a summary statement of undisputed points. We both 
agree that the cost of replacing plant consumed over the years is an expense of rendering service. We both agree that an allowance for this cost must be included in the rates which utility companies are permitted to charge for service. We both agree that the Company receives as cash the customer payments made in accordance with permitted rates. The difference of opinion revolves about the treatment to be accorded to those amounts which companies are permitted to collect from customers for a particular purpose prior to the corresponding property retirements.

No solution or agreement is possible so long as the two problems arc treated as one and camouflaged by plausible phrases such as are contained in Dr. Bauer's article. Stripped of misleading verbiage, Dr. Bauer and the NARUC report recommend the amortization of capital, under the pretense of accounting for depreciation. If amortization is to be adopted as a public policy, its merits should be debated publicly rather than attained by indirection or by slavish adherence to accounting conventions. ${ }^{23}$

23. See concurring opinion of Mr. Justice Jackson in Federal Power Comm. v. Hope Natural Gas Co., 320 U. S. 591, 643-44, n. 40 (1944):

"To make a fetish of mere accounting is to shield from examination the deeper causcs, forces, movements, and conditions which should govern rates. Even as a recording of current transactions, bookkeeping is hardly an exact science. As a representation of the condition and trend of a business, it uses symbols of certainty to express values that actually are in a constant flux. It may be said that in commercial or investment banking or any business extending credit success depends on knowing what not to believe in accounting. Few concerns go into bankruptcy or reorganization whose books do not show them solvent and often even profitable. If one cannot rely on accountancy accurately to disclose past or current conditions of a business, the fallacy of using it as a sole guide to future price policy ought to be apparent. However, our quest for certitude is so ardent that we pay an irrational reverence to a technique which uses symbols of certainty, even though experience again and again warns us that they are delusive..." 